\title{
BELONOCHILUS NUMENIUS (SAY, 1832) (HETEROPTERA: LYGAEIDAE), A NEW INVASIVE SPECIES IN CROATIA
}

\author{
Matea Martinović ${ }^{1 *}$, Anton Gjeldum ${ }^{2}$ \& Toni Koren ${ }^{3}$ \\ ${ }^{1}$ Dubrovnik Natural History Museum, Androvićeva 1, HR-20000 Dubrovnik, Croatia \\ (e-mail: matea.martinovic@pmd.hr) \\ ${ }^{2}$ City of Split, Obala kneza Branimira 17, HR-21000, Split, Croatia (e-mail: anton.gjeldum@split.hr) \\ ${ }^{3}$ Association Hyla, Lipovac I no. 7, HR-10000 Zagreb, Croatia (e-mail: toni.koren@hhdhyla.hr)
}

Martinović, M., Gjeldum, A. \& Koren, T.: Belonochilus numenius (Say, 1832) (Heteroptera: Lygaeidae), a new invasive species in Croatia. Nat. Croat., Vol. 29, No. 2., 479-482, 2019, Zagreb.

In the present paper we report first observations of the invasive sycamore seed bug, Belonochilus numenius (Say, 1832) in Croatia. So far, we recorded the species in five localities in Croatia, one in Zagreb, two in Split and two in and around Dubrovnik. All the records originate from the urban areas with Plane trees on which the species feeds.

Key words: alien species, plane tree, true bugs, distribution

Martinović, M., Gjeldum, A. \& Koren, T.: Belonochilus numenius (Say, 1832) (Heteroptera: Lygaeidae), nova invazivna vrsta u Hrvatskoj. Nat. Croat., Vol. 29, No. 2., 479-482, 2019, Zagreb.

U ovom radu iznosimo prva opažanja invazivne dugonose platanine stjenice, Belonochilus numenius (Say, 1832) u Hrvatskoj. Do sada je vrsta zabilježena na pet lokaliteta, jednom u Zagrebu, dva u Splitu te dva u i oko Dubrovnika. Svi nalazi potječu iz urbanih područja na kojima rastu platane kojima se vrsta hrani.

Ključne riječi: alohtone vrste, platana, stjenice, rasprostranjenost

The sycamore seed bug Belonochilus numenius (Say, 1832) is an invasive lygaeid species native to Nearctic region, i.e. Canada, USA and Mexico (Ashlock, 1967). It is an arboreal seed predator, with both adults and nymphs feeding on mature and immature fruits of Platanus spp. (WheELER, 1984). In Europe it was detected more than a decade ago, with the first records dating back to 2008 from Spain (Gessé et al., 2009) and France (MatocQ, 2008). Since then, it presence was confirmed in many European countries, including the ones bordering Croatia: Italy (CARAPEZZA \& Cusimano, 2014), Slovenia (Gogala et al., 2016), Hungary (Torma, 2012), Serbia (Protić \& Š́eat, 2016) and Bosnia \& Herzegovina (Kulijer \& Miljević, 2016). Accordingly, it was only a matter of time before it is found in Croatia as well.

In the present paper, first records of B. numenius in Croatia are reported. Identification of the species (Fig. 1) was based on morphological characters described by Gessé et al. (2009). The collected specimens are stored in the entomological collection of the Dubrovnik Natural History Museum (PMD). So far, this species has been recorded in five localities in Croatia (Fig. 2).

\footnotetext{
* corresponding author
} 


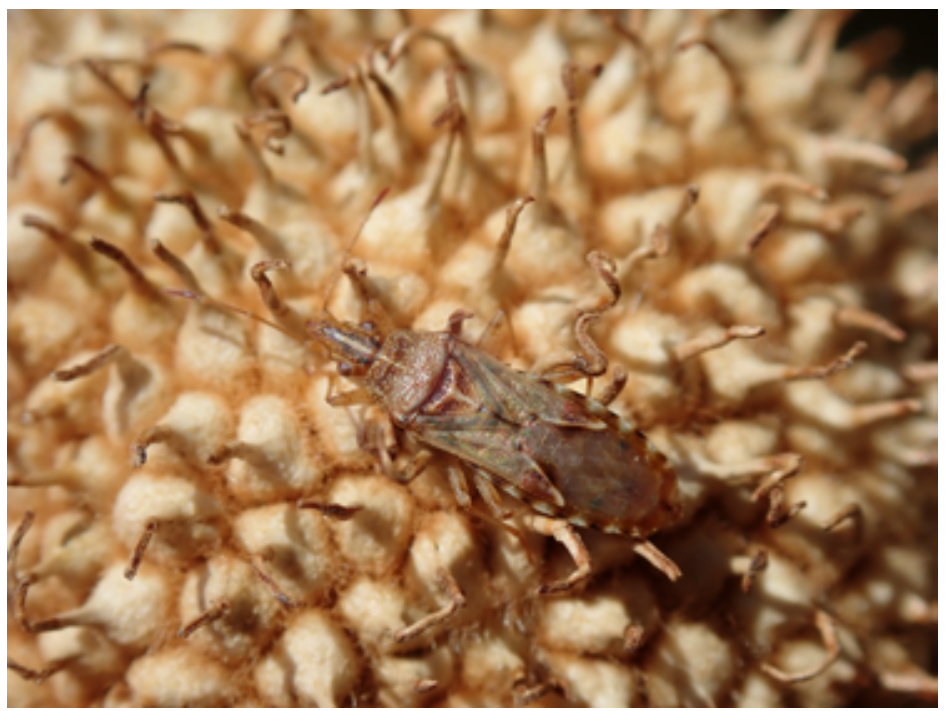

Fig. 1. Belonochilus numenius photographed on Platanus orientalis in Dubrovnik city. Photo by T. Koren.

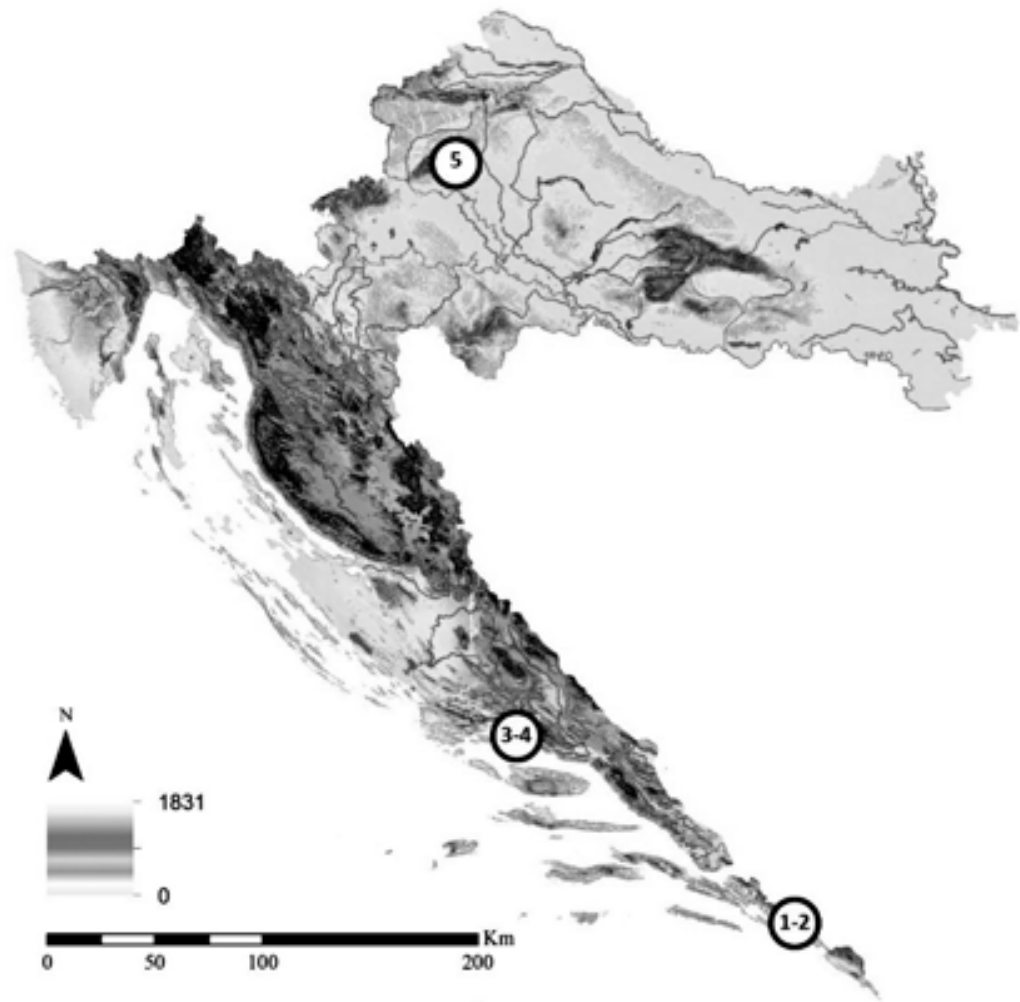

Fig. 2. Distribution of Belonochilus numenius in Croatia. 1. Dubrovnik, Pile, 2. Dubrovnik, Komolac, 3. Split, Poljud, 4. Split, Lovret, 5. Zagreb, Jarun. 
Records of B. numenius:

1. Dubrovnik, Pile, 42.642375 N, 18.106147 E, 30.V.2019,1 adult, numerous larvas; 29.X.2019, numerous adults, 8.XI.2019, numerous adults and mating pairs, leg. \& obs. M. Martinović, T. Koren.

2. Dubrovnik, Komolac, 42.673201 N, 18.135820 E, 10.XI.2019., numerous adults, leg. \& obs. M. Martinović

3. Split, Poljud, 43.516777 N, 16.433132 E, 07.VII.2019, 1 adult; 03.XI.2019., 4 adults, obs. A. Gjeldum.

4. Split, Lovret, 43.513002 N, 16.435906 E, 03.XI.2019., numerous adults, obs. A. Gjeldum.

5. Zagreb, Jarun, 45.783090 N, 15.926928 E, 28.X.2019., 1 adult, obs. I. Bravić

On May $30^{\text {th }} 2019$, a single adult specimen of B. numenius was collected on a branch of the Oriental Plane tree, Platanus orientalis L., right at the entrance of the Dubrovnik Old Town. At the same time, all of the mature fruits (seed balls) reachable from the ground were examined. Most of them were inhabited by different larval stages of $B$. numenius. Same location was visited later in the season, during October and November when numerous adult specimens and mating pairs were observed mostly on globular fruits, suggesting that the population of B. numenius was well established. Second locality where it was recorded in Dubrovnik area was in Komolac by the river Ombla. During the same year, additional records from Split and Zagreb were gathered. In Split, the first specimen was recorded dead in a light lamp in a family home. Afterwards, numerous adults were observed in a nearby park and at one additional locality on Platanus spp. Finally, a photographed record from Zagreb city was reported in a Facebook group "Koji je ovo pauk/kukac?" ("What insect/spider is this?").

According to WheELER (1984) the specimens we observed in the end of May may belong to the first generation, while the ones from the end of October and the beginning of November may belong to the $4^{\text {th }}$ generation.

While limited, these records indicate a wide distribution in Croatia. Further visits to different urban parks with Plane trees in Croatia will surely result in additional records. With its feeding habits $B$. numenius does not make any damage to the tree, but in case of larger population outbreaks, it may become a public nuisance as reported from Spain (Riba et al., 2015). Therefore, its population in Croatian urban areas should be monitored, especially in locations with frequent public activities, like Dubrovnik Old Town entrance and others.

As the species does not yet have a vernacular name, we suggest "dugonosa platanina stjenica" to be used when referring to this species in Croatia.

\section{ACKNOWLEDGMENTS}

We are grateful to Izabela Bravić for sharing and allowing us to add her observation of B. numenius from Zagreb to our manuscript. 


\section{REFERENCES}

Ashlock, P. D., 1967: A generic classification of the Orsillinae of the World (Hemiptera: Heteroptera: Lygaeidae). University of California Publications in Entomology 48, 1-82.

Carapezza, A. \& Cusimano, C., 2014: Heteroptera in the aeroplancton of Palermo town, with two new records for Italy (Hemiptera Heteroptera). Naturalista Siciliano 38, 367-380.

Gessé, F., Ribes, J. \& Goula, M., 2009: Belonochilus numenius, the sycamore seed bug, new record for the Iberian fauna. Bulletin of Insectology 62(1), 121-123.

Gogala, A., Kamin, J. \& Zdešar, M., 2016: Three new records of Heteroptera in Slovenia. Acta Entomologica Slovenica 24(1), 55-58.

Kulijer, D. \& Miljević, I., 2016: First report of Belonochilus numenius (Say, 1832) in Bosnia and Herzegovina (Heteroptera: Lygaeidae). Folia Historico - Naturalia Musei Matraensis 40, 61-63.

Matoce, A., 2008: Presence en France et en Corse d'un Heteroptere nearctique, Belonochilus numenius (Say, 1831) (Hemiptera, Lygaeidae, Orsillinae). Bulletin de la Societe Entomologique de France 113, 533-534.

Protić, L. \& ŠEAT, J., 2016: First records of the alien sycamore seed bug Belonochilus numenius in Serbia (Heteroptera: Lygaeidae). Acta Entomologica Serbica 21, 13-19.

Riba, J.M., Marti, I. \& Goula, M., 2015: Updating data on the sycamore seed bug Belonochilus numenius (Say, 1832) (Hemiptera: Lygaeidae) in Spain. Butlletí de la Institució Catalana d'Història Natural 79, 157-163.

Torma, A., 2012: A Belonochilus numenius (Heteroptera: Lygaeidae) adventív poloskafaj első magyarországi elöfordulása. / First record of the alien sycamore seed bug Belonochilus numenius (Heteroptera: Lygaeidae) in Hungary. Növényvédelem 48(10), 467-468.

Wheeler, A. G. JR., 1984: Seasonal history, habits and immature stages of Belonochilus numenius (Hemiptera: Lygaeidae). Proceedings of the Entomological Society of Washington 86, 790-796. 